http://dx.doi.org/10.12775/szhf.2014.046

\author{
Marta SzymańsKa-LewoszewsKa
}

\title{
Berkeley's Theodicy in A Treatise Concerning the Principles of Human Knowledge (1710)
}

\author{
"[...] For, after all, what deserves the first place in our studies \\ is the consideration of GOD and our duty;" \\ G. Berkeley, A Treatise Concerning the Principles of Human Knowledge, $\$ 156^{1}$.
}

The term 'theodicy', as it was used by G. W. Leibniz, who introduced it in his Essais de théodicée sur la bonté de dieu, la liberté de l'homme, et l'origine du mal in 1710, literally meant 'justice of God'. It has since, however, acquired a more complex meaning. According to the Dictionary of the History of Ideas, in a narrow sense it means (i) "the defense of God, the supreme creator, ruler, and judge of the universe, against charges brought about by a consideration of both moral and natural evil"; (ii) "a kind of science, as it were, namely the doctrine of the justice of God-that is, of his wisdom together with his

* This research has been funded by the National Science Centre in Poland as part of the postdoctoral internship based on decision DEC-2014/12/S/HS1/00153.

${ }^{1}$ G. Berkeley, A Treatise Concerning the Principles of Human Knowledge, [PHK], The Works of George Berkeley ed. A. A. Luce and T. E. Jessop (9 vols.; London-Edinburgh-Paris-Melbourne-Toronto-New York: Thomas Nelson and Sons Ltd., 1948-1957), vol. 2, p. 113.

${ }^{2}$ L. L. Loemker, Theodicy, [in:] The Dictionary of the History of Ideas, ed. P. Wiener, 4 vols. (New York: Scribner, 1973, vol. 4, p. 379). 
goodness"', and (iii) philosophical theology. For the purpose of this paper, theodicy will be considered in its second meaning, which was also accepted by Leibniz.

The first edition of A Treatise Concerning the Principles of Human Knowledge (later referred to as Principles) by George Berkeley appeared in 1710. The philosopher explained the aim of it in his letter to Sir John Percival. It was connected with his earlier work, i.e. An Essay Towards a New Theory of Vision (1709). Berkeley hoped to make its content subordinate to the ends of morality and religion and persuade the reader to focus their studies on the two areas. In Principles he wanted to demonstrate the existence and attributes of God and the immortality of the soul, as well as to reconcile God's foreknowledge with the freedom of $\mathrm{men}^{4}$. The full title of the work, i.e. A Treatise Concerning the Principles of Human Knowledge wherein the Chief Causes of Error and Difficulty in the Sciences, with the Grounds of Scepticism, Atheism, and Irreligion, are inquired into, as well as paragraph 4 of the Introduction section, and the paragraph 156 of the main text agree with the aims outlined in the letter. However, the problem of the reconciliation of God's foreknowledge with the freedom of men is not discussed in the Principles directly.

The analysis of the mentioned paragraphs reveals Berkeley's assumptions of God's presence in the world and goodness of His creation. They serve as the grounds which enable "[...] to suspect that those lets and difficulties, which stay and embarrass the mind in its search after truth, do not spring from any darkness and intricacy in the objects, or natural defect in the understanding, so much as from false principles which have been insisted on, and might have been avoided" . It seems thus that what is responsible for the wrong way of reasoning is not the object itself, but the free will which man is gifted by God. What seems to be problematic in the light of the gift is the limit of it. Why does God allow man to use false principles which distance them from God and their duty of practicing the truths of the Gospel, which is the highest perfection of human nature? Can evil in its metaphysical, physical and moral sense be considered as a sign of God's presence in the world? Those questions are to be considered in this paper. In the course of the analysis of the Principles, I shall try to reconstruct Berkeley's views on the nature of God

\footnotetext{
${ }^{3}$ L. L. Loemker, Theodicy, ... p. 379.

${ }^{4}$ G. Berkeley, Letter to Sir John Percival, March 1710, [in:] The Works of George Berkeley, vol. 8, p. 31.

${ }^{5}$ [PHK] Introduction, $\$ 4$, vol. 2, p. 26.
} 
and his Providence, as well as the problem of evil and the meaning of justice. The purpose of the analysis is to show Berkeley's concern for the problem which was discussed at the time, as well as to present his own solution to it.

\section{The nature of God and His Providence}

Throughout the Principles God is referred to by Berkeley with the use of different terms, i.e. Spirit, Mind, Creator, superior or active principle, Agent, Author, Author of nature. The choice of terminology stresses the character of the being of God, which is different from that of ideas. As Berkeley explains in a general definition of a spirit, which refers both to the finite spirits of men and the infinite and uncreated spirit of God, "[...] the words will, [understanding, mind], soul, spirit, do not stand for different ideas, or in truth, for any idea at all, but for something which is very different from ideas, and which, being an agent, cannot be like unto, or represented by, any idea whatsoever"6. In the light of the thesis of esse est percipi God is a spirit, an incorporeal active substance because he is active, i.e. he thinks, wills, and perceives ${ }^{7}$. The words: Creator and Author indicate the relation of dependence between God and ideas - it is the spirit that is solely responsible for their existence ${ }^{8}$. In comparison to the finite spirits of men, the spirit of God is characterized by the following adjectives which inform us about his attributes: governing ${ }^{9}$, supreme $^{10}$, free ${ }^{11}$, all-sufficient ${ }^{12}$, all-wise ${ }^{13}$, omnipotent ${ }^{14}$, Almight $^{15}$, as well as "one, eternal, infinitely wise, good, and perfect. He is described as the one 'who works all in all,' and 'by whom all things consist,"'16 "[...] who fashions, regulates and sustains the whole system of beings," ${ }^{17}$ and above all "[...] who is intimately present to our minds, producing in them all that variety of ideas or sensations which continually affect us, on whom we have an absolute

\footnotetext{
${ }^{6}$ PHK, $\$ 27$, p. 53.

${ }^{7}$ See: PHK, \$138, p. 104; PHK, \$139, p. 104-105.

${ }^{8}$ See: PHK, \$29, p. 53; PHK, \$146, p. 107-108.

${ }^{9}$ See: PHK, §32, p. 54; PHK, \$44, p. 59; PHK, \$106, p. 91.

${ }^{10}$ See: PHK, \$57, p. 65; PHK, \$81, p. 75.

${ }^{11}$ PHK, $\$ 57$, p. 65.

${ }^{12} \mathrm{PHK}, \$ 74$, p. 73.

${ }^{13}$ PHK, \$151, p. 111.

${ }^{14}$ PHK, \$152, p. 111.

${ }^{15}$ PHK, $\$ 155$, p. 112.

${ }^{16}$ PHK, $\$ 146$, p. 108. See also: PHK, \$151, p. 110-111.

${ }^{17}$ PHK, \$151, p. 111.
} 
and entire dependence, in short „,in whom we live, and move, and have our being"18.

It is only God's will which is responsible for the constitution of the laws of nature according to Berkeley ${ }^{19}$. We know of their existence due to the perception of the visible ideas which constitute, as the philosopher wrote in $A n$ Essay Towards a New Theory of Vision, the Language of Nature (1709) or the Language of the Author of Nature (1732). The language instructs us "how to regulate our Actions, in order to attain those things that are necessary to the Preservation and Well-being of our Bodies, as also to avoid whatever may be hurtful and destructive of them" 20 . The knowledge of this fact is very important, as by nature, the spirit can be perceived by the effects which it produces $^{21}$. And the effects clearly indicate that "the whole creation is a workmanship of $a$ wise and good agent"22. It is important to stress that Berkeley distinguishes his view from the representationalism of Malebranche when he writes that, "Not that I imagine we see God (as some will have it) by a direct and immediate view - or see corporeal things, not by themselves, but by seeing that which represents them in the essence of God, which doctrine is, I must confess, to me incomprehensible ${ }^{23}$.

For Berkeley the perception of spirits is limited to the way they are marked out by ideas. Man meant as an active principle, that moves, perceives and thinks is not directly visible in the act of perception. It is only through different ideas which are present to human eyes in their act of perceiving, like the color, size, figure or motions of a man that we can know of the existence of that principle of motion as Berkeley writes in paragraph $148^{24}$. A similar situation occurs when it comes to the perception of God. As Berkeley claims, "we do at all times and in all places perceive manifest tokens of the Divinity: every thing we see, hear, feel, or anywise perceive by sense, being a sign or

\footnotetext{
${ }^{18}$ PHK, \$149, p. 109.

${ }^{19} \mathrm{PHK}, \S 32$, p. 54. In general, Berkeley referred to two kinds of laws of nature. In paragraph 33 of Passive Obedience Berkeley distinguished physical laws of nature which are non-changeable and natural laws which obtain in the moral world and imply a duty on men. (See: G. Berkeley, Passive Obedience, \$33, [in:] The Works of George Berkeley, vol. VI, p. 35) Here, in $\$ 32$ of the Principles the laws of nature denote physical laws.

${ }^{20}$ G. Berkeley, An Essay Towards a New Theory of Vision \$147, [in:] The Works of George Berkeley, vol. 1, p. 231; PHK, \$44, p. 151-152.

${ }^{21}$ See: PHK, $\$ 27$, p. 52-53.

${ }^{22}$ PHK, $\$ 107$, p. 88.

${ }^{23}$ PHK, $\$ 148$, p. 108-109.

${ }^{24}$ See: PHK, \$148, p. 109.
} 
effect of the power of God; as is our perception of those very motions which are produced by men" 25 . Since the manifestations of God are so clear, his existence cannot be more evident for Berkeley ${ }^{26}$.

In the light of the above considerations, two questions arise. First, if the existence of God is the most evident, why does He allow atheism, let people deny their dependence on $\mathrm{Him}^{27}$, and persist in a remorseless violation of his Laws $^{28}$ ? Second, what is the place, if any, for evil is such a perfect creation? On the one hand Berkeley's God is more than a deistic clockmaker on the other - more than a theistic author of occasional miracles. The voluntaristic concept of $\mathrm{God}^{29}$, shared by the philosopher, allows a possibility of aberrance from the regularity and uniformity of His operations. As Berkeley writes, "Such exceptions from the general rules of nature are proper to surprise and awe men into an acknowledgement of the divine being: but then they are to be used but seldom, otherwise there is a plain reason why they should fail of that effect" ${ }^{\prime 3}$. The anomalous and surprising events are, however, referred to in terms of some positive miracles rather than negative catastrophes. They are thought to have some power persuading us of the existence of $\mathrm{God}^{31}$. Nevertheless, we may think of an example when the anomaly is not a miracle at all. Should we thus treat the resulting evil as a conscious effect of God's inconsistency which is an imperfection or as an unconscious side-effect of the uniformity of his action? If the course of nature was interrupted by a catastrophe, would men be ready to admit the presence of a superior agent, i.e. the wise, good and perfect God?

\section{The Problem of Evil and Justice}

The problem of evil was broadly discussed at the time of the publishing of both editions of the Principles. Leibniz's Theodicy (1710) was published in parallel with the $1^{\text {st }}$ edition of Berkeley's work. The publication of the second edition was preceded by Alexander Pope's four epistles of An Essay on Man published in 1734. Moreover, the discussion on evil was possibly influenced

\footnotetext{
${ }^{25}$ PHK, $\$ 148$, p. 109.

${ }^{26}$ See: PHK, \$149, p. 109.

${ }^{27}$ PHK, \$149, p. 109.

${ }^{28}$ See: PHK, $\$ 155$, p. 112.

${ }^{29}$ See: PHK, $\$ 106$, p. 87.

${ }^{30}$ PHK, \$63, p. 68.

${ }^{31}$ See: PHK, $\$ 57$, p. 60.
} 
by some earlier works, i.e. Pierre Bayle's Dictionnaire historique et critique (1697) and William King's De Origine Mali (An Essay on the Origin of Evil) (1702). Berkeley was familiar with the works by King and Pope ${ }^{32}$. The study of the Principles proves that Berkeley was aware of the importance of the issue of evil. Despite of this, rarely does the term 'evil' appear in the Principles. It is also used in different meanings there. It refers to some events resulting either from the course of nature or human choices which may be considered by us as unpleasant ${ }^{33}$. Also, it signifies "the absurd opinions and insignificant disputes which grow out of the abuse of words" ${ }^{34}$, or the acceptance of the existence of matter ${ }^{35}$.

According to Berkeley, evil and some particular events which may be referred to as evil cannot be identified as one thing. It is the human perspective which is responsible for accounting different events as evil. The reason is its being finite and imperfect. Here, however, Berkeley understands imperfection as something which is partial. Human prospects are finite, thus in regard to the infinite prospects of God they are narrow or incomplete. That influences human perception of pain or uneasiness as evil, which in fact however, are not evil. Only they appear to be so, since, as Berkeley writes in paragraph 153, when considered as linked with the whole system of beings, they have the nature of good. Hence, the nature of an idea depends on the perspective from which it is looked at, and evil is a category relevant to the finite one, which is illusory or apparent. The line of argumentation refers to the pain and uneasiness resulting both from the general laws of nature and actions of finite and imperfect spirits. ${ }^{36}$ What is more, evil as such is considered to be "in the state we are in at present, [...] indispensably necessary to our wellbeing" ${ }^{37}$. The blemishes and defects which are present in the course of nature ${ }^{38}$ do not deprive it of its being perfect. On the contrary, they emphasize it. What may seem to be a sign of lack of God's hand in the course of nature stands for a proof of His existence and Providence in fact. The purpose of the defects for Berkeley is that "they make an agreeable sort of variety, and augment the

32 J. P. Hershbell, Berkeley and the Problem of Evil, [in:] Journal of the History of Ideas, Vol. 31, No. 4, (Oct.-Dec., 1970), pp. 543-544.

${ }^{33} \mathrm{PHK}$, Introduction, $\$ 20$, p. 37-38.

${ }^{34}$ PHK, Introduction, $\$ 23$, p. 50.

${ }^{35}$ PHK, $\$ 133$, p. 102.

${ }^{36}$ PHK, $\$ 153$, p. 111-112.

${ }^{37}$ PHK, $\$ 153$, p. 111.

${ }^{38}$ PHK, \$152, p. 111. 
beauty of the rest of the creation, as shades in a picture serve to set off the brighter and more enlightened parts" ${ }^{\prime 3}$.

It remains problematic however, whether the above reasoning can justify the existence of atheism, skepticism or irreligion and the other phenomena which are the results of human action and may be accounted as evil from the perspective of mankind. If it can, then, first, there is no reason for Berkeley to write any treatises which have the aim of eradicating evil which results from the actions of finite spirits. Secondly, men are allowed to do whatever they want, as they can always justify their wrong actions with the help of the infinite perspective in which the evil they commit is a good deed. It is rather dubious that Berkeley would agree with such reasoning, especially with regard to what he writes in paragraph 155: "[...] it is downright impossible that a soul pierced and enlightened with a thorough sense of the omnipresence, holiness, and justice of that Almighty Spirit should persist in a remorseless violation of His laws" ${ }^{\prime \prime}$. And the laws he refers to here are both the Natural Law and the Ten Commandments.

Therefore, we could ask, why God still allows men to follow the wrong path. As Berkeley writes in paragraph 151 of the first edition of the Principles, "[...] the finger of God is not so conspicuous to the resolved and careless sinner, which gives him an opportunity to harden in his impiety and grow ripe for vengeance" ${ }^{41}$. We may speculate whether the answer could be the gift of free will which is bestowed on man. Berkeley, however, does not consider that issue in the Principles in an explicit way. It can only be inferred from what he states at the very beginning of paragraph 3 of the Introduction to the Principles. He writes that men owe the difficulties on the way to knowledge entirely to themselves. God furnishes men with means that enable them the satisfaction of the knowledge which they naturally have a strong desire of ${ }^{42}$. Thus, it is man himself who decides about the way he uses his faculties. The possibility of fault may result either from the free will which is bestowed in man by God or the human nature which, according to the Anglican doctrine, is inclined to evil unless it is subject to the law of $\mathrm{God}^{43}$.

What is the ontological status of evil according to the point of view presented by Berkeley in the Principles? Evil, as it is described in the Principles has

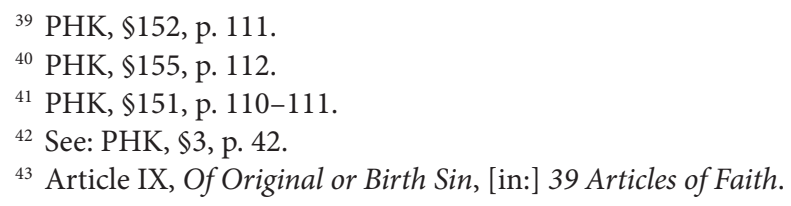


no real existence. The system in the Principles, unlike Manichaeism, which is a heresy according to Berkeley ${ }^{44}$, is monistic. There is only one active substance, i.e. a good and wise Spirit ${ }^{45}$ that is the Author of nature. In the light of the Principles, evil would have to be an abstract idea, the existence of which is criticized by Berkeley. Thus, it can only be a general notion ${ }^{46}$. Its being is limited to its functioning, which brings about the emotive purpose of language introduced by Berkeley in paragraph 20 of the Principles ${ }^{47}$. In that meaning, the notion of 'evil' exists as it raises some passions, excites or deters from an action and puts human mind in some particular disposition.

As such, Berkeley's view on evil, although not discussed at large in the Principles, stays in opposition to the ones held by Manicheans and Socinians which are the object of Berkeley's criticism on the grounds that, in both of them, evil was accepted as coexistent with the good $^{48}$. For Berkeley, evil does not exist on the level of God's creation which is good from its nature. What is more, on the grounds of the Principles, it is not yet characterized as a result of the deviated human free will. Evil, as it appears in the Principles, functions as a category used by finite spirits for naming the painful, unpleasant results of their actions and the general laws of nature, which are good by nature. Berkeley however does not provide any explanation for such identification. Although it seems that he accepts St. Augustine's Privative Theory of Evil, he does not explicitly admit that a painful or an unpleasant event is called evil because it lacks good. It seems then that Berkeley's use of the term 'evil' "[...] is not to distinguish and identify objects of perception, but to express attitudes, to formulate rules, announce aims, and to guide and to control the practices essential to the conduct of life" ${ }^{\prime \prime}$.

\footnotetext{
${ }^{44}$ PHK, $\$ 154$, p. 112.

${ }^{45}$ PHK, \$7, p. 43-44.

${ }^{46} \mathrm{PHK}, \$ 100$, p. 84.

${ }^{47}$ See: PHK, Introduction $\$ 20$, p. 37.
}

${ }^{48}$ What is more, Socinians claimed that the existence of evil is incompatible with God who is all-knowing. See: M. Murray, Leibniz on the Problem of Evil, first published Jan 4, 1998, revised Mar 16, 2005[in:] Stanford Encyclopedia of Philosophy: http://plato.stanford.edu/entries/ leibniz-evil/. The problem, although intended by Berkeley, was not discussed in the Principles. However, on the grounds of Berkeley's denial of the existence of evil, we may suppose his criticism of Socinians' point of view, which is also shared by G. W. Leibniz in paragraph 364 of his Theodicy.

${ }^{49}$ H. D. Aiken, The Fate of Philosophy in the Twentieth Century, The Kenyon Review, Spring 1962, quoted after P. Olscamp, The moral philosophy of George Berkeley, p. 131. 
In the light of the above remarks, it is worth considering David Berman's claim that "Berkeley, however, explained only religious mysteries emotively. He was entirely clear that doctrines of natural theology were to be understood cognitively and justified in a rigorous way" ${ }^{50}$. It would imply that evil could have been treated by the philosopher as a religious mystery. Berkeley believes, as Berman writes, that Christian mysteries are the best ways of evoking the desirable attitude of respect and the feeling of love towards God $^{51}$. Since evil may turn out to be good in the wider perspective, we should need no better encouragement to believe God being all-knowing as well as all-wise. In addition to this, we should trust His laws, even when the obedience to them means facing the risk of the loss of life ${ }^{52}$.

Throughout the Principles neither does Berkeley define nor explain what evil is. The explanation of the lack of either is given in paragraph 100 where the philosopher writes about the uselessness of abstract ideas with regard to morality. It was considered by him to be the most useful part of knowledge, yet practical and not theoretical in character. In the philosopher's opinion "[...] a man may be just and virtuous without having precise ideas of justi$c e$ and virtue. The opinion that those and the like words stand for general notions, abstracted from all particular persons and actions, seems to have rendered morality [very] ${ }^{53}$ difficult, and the study thereof of $<$ small $>^{54}$ use to mankind" ${ }^{55}$. The quoted words may serve as a justification for Berkeley not taking up the problem of justice as well.

Are we then justified in our search for theodicy on the grounds of Berkeley's Principles in the way it was understood by Leibniz? Berkeley's intention in the Principles was to inspire the reader with the sense of God's presence in the world. In the closing paragraph of the work Berkeley writes, "For, after

${ }^{50}$ D. Berman, George Berkeley, [in:] British Philosophy and the Age of Enlightenment, ed. S. Brown, (Taylor \& Francis e-Library, 2004), vol. 5 of Routledge History of Philosophy, ed. by G. H. R. Parkinson and S. G. Shanker, (10 vols., London, New York: Routledge, Taylor \& Francis Group 1993-1999), p. 114.

${ }^{51}$ See: D. Berman, George Berkeley, pp. 114-115.

${ }^{52}$ The problem is broadly discussed in Passive Obedience (1712).

${ }^{53}$ The word was omitted in the $2^{\text {nd }}$ edition of the Principles.

${ }^{54}$ The word was replaced with: 'less' in the $2^{\text {nd }}$ edition of the Principles.

${ }^{55}$ PHK, $\$ 100$, p. 84-85. 
all, what deserves the first place in our studies is the consideration of God and our duty; which to promote, as it was the main drift and design of my labours [...]"56. It seems thus, that the sense of Berkeley's theodicy is not so much the apology of God's presence in the world and his constant care for man but rather a discipline the subject of which is the analysis of the existence as well as the nature of $\operatorname{God}^{57}$. The order of the world persuades us enough of God's authorship of it, as He alone is the immediate efficient cause of all things ${ }^{58}$. As Berkeley often repeats the words of St. Paul (Acts 17:28), it is God "in whom we live, move and have our being" ${ }^{59}$. It is then sufficient for him to conclude in paragraph 107, that

considering the whole creation is the workmanship of a wise and good Agent, it should seem to become philosophers to employ their thoughts (contrary to what some hold) about the final causes of things; [for besides that this would prove a very pleasing entertainment to the mind, it might be of great advantage in that it not only discovers to us the attributes of the Creator but may also divert us in several instances to the proper uses and applications of things] ${ }^{60}$.

The part of paragraph 107 in square brackets which was deleted in the second edition of the Principles enhances the real purpose of the work. It is not to criticize human wrongdoing but to show the reason for it which lies not in their nature but in the wrong use of the human faculties. This also justifies the attention which Berkeley pays to the esse est percipi thesis and the immaterialist consequences of it. The optics of looking at the world as God's creation through the prism of the final causes justifies the nature of reflection upon evil in the Principles. It focuses more on the role of evil in human life than on its ontological status which is nonexistent, since evil, as a general notion, seems to function only on the level of human language. Pain and uneasiness which are identified with evil contain some information given by God, the

\footnotetext{
${ }^{56}$ PHK, \$156, p. 113.

${ }^{57}$ As it turns out, the demonstration of the existence of God is impossible. The general laws of nature which inform us of the God's operation in the world enable only deduction as the uniformity of God's operation are only supposed and not known evidently. See: PHK, \$107, p. 92.

${ }^{58}$ See: PHK, §53, p. 63.

${ }^{59}$ Acts, 17:28.

${ }^{60}$ PHK, \$107, p. 88.
} 
deciphering of which is our duty ${ }^{61}$. Berkeley reminds us of it in paragraph 109 , where he writes that,

We should propose to ourselves nobler views, namely, to recreate and exalt the mind with a prospect of the beauty, order, extent, and variety of natural things: hence, by proper inferences, to enlarge our notions of the grandeur, wisdom, and beneficence of the Creator; and lastly, to make the several parts of the creation, so far as in us lies, subservient to the ends they were designed for, God's glory, and the sustentation and comfort of ourselves and fellow-creatures ${ }^{62}$.

In the light of above remarks, the following words of Austin Farrer, the author of the editor's introduction to Leibniz's Theodicy do not quite seem to be just. Farrer claims that both philosophers are similar but different at the same time. In general, they are authors of peculiar philosophies. On the other hand, however, they are not comparable as far as being consequent in their method of philosophizing is concerned. "About many things," Farrer says, "Berkeley never took the trouble to Berkeleianize. To take the most surprising instance of his neglect - he assured the world that his whole doctrine pointed to, and hung upon, theology. But what sort of a theology? He scarcely took the first steps in the formulation of it. He preferred to keep on defending and explaining his esse est percipi. With Leibniz it is wholly different; he carries his new torch into every corner, to illuminate the dark questions" ${ }^{\prime \prime}$.

Berkeley's defense and explanation of esse est percipi served the theological problems which the philosopher did consider in his works where the study of God always remained the central one. However, with the expulsion of matter out of nature ${ }^{64}$, which is the view that Leibniz himself agreed with although he considered it to have been too paradoxically expressed by Berkeley $^{65}$, Berkeley seemed to believe to encounter no dark questions in need of being illuminated so much. At least in the time of writing the first edition

\footnotetext{
${ }^{61}$ See: PHK, 665 , p. 69.

${ }^{62}$ PHK, $\$ 109$, p. 89.

${ }^{63}$ A. Farrer, Editor's Introduction, [in:] W. Leibniz, Theodicy, Essays on the Goodness of God, the Freedom of Man and the Origin of Evil, Routledge \& Kegan Paul Limited, London 1951, The Project Gutenberg EBook, November, 24, 2005, p. 11. http://www.gutenberg.org/ files/17147/17147-h/17147-h.htm

${ }^{64}$ PHK, $\$ 96$, p. 82.

${ }^{65}$ Leibniz expressed that view in a note written on the last page of the copy of Berkeley's Principles. See: R. M. Adams, Leibniz. Determinist, Theist, Idealist, (New York: Oxford University Press, 1994), p. 224.
} 
of Principles, the philosopher seemed to think that the excess of light might have had a blinding power.

\section{Bibliography}

Primary sources:

Berkeley, G. The Works of George Berkeley ed. A. A. Luce and T. E. Jessop, 9 vols.; London-Edinburgh-Paris-Melbourne-Toronto-New York: Thomas Nelson and Sons Ltd., 1948-1957.

Leibniz, G. W., Theodicy, Essays on the Goodness of God, the Freedom of Man and the Origin of Evil, London: Routledge \& Kegan Paul Limited, 1951, The Project Gutenberg EBook: November, 24, 2005.

Secondary sources:

Adams, R. M. Leibniz. Determinist, Theist, Idealist, New York: Oxford University Press, 1994.

Hershbell, J. P. "Berkeley and the Problem of Evil”, Journal of the History of Ideas, 31, No. 4, (1970): 543-554.

Routledge History of Philosophy, ed. by G. H. R. Parkinson and S. G. Shanker, 10 vols., London-New York: Routledge, Taylor \& Francis Group 1993-1999.

The Dictionary of the History of Ideas, ed. P. Wiener, 4 vols., New York: Scribner, 1973.

\section{Abstract \\ Berkeley's Theodicy in A Treatise Concerning the Principles of Human Knowledge (1710)}

In this article I attempt to reconstruct Berkeley's views on the nature of God and his Providence, as well as the way he refers to the problem of evil and justice in the world. My analysis is based on one of the early works by Berkeley, i.e. Principles of Human Knowledge (1710). Its aim is to present Berkeley's understanding of theodicy as different from the one suggested by Leibniz in Theodicy (1710).

Key words: Berkeley, God, evil, theodicy, justice 